\title{
The Development of Family Planning in Finland from the 1960s to the 1990s
}

Marketta Ritamies, M.Soc.Sc.

Senior Researcher

The Population Research Institute

\section{Abstract}

The purpose of this article is to examine the development of family planning in Finland from the 1960s to the 1990s by comparing the results from several studies representing the entire country. First we will examine ideals concerning family size and the spacing of children. We will then focus on the conditions necessary for families to realize these ideals, which will include an examination of what families know about birth control and what contraceptive methods are available to them. Finally we will assess how family size ideals were realized - did the final number of children correspond to the family size set as a goal.

In the 1960s and the 1970s Finns were already considering a relatively small family as ideal, and essentially there has been no change in this ideal. The realization of family size ideals was still hindered in the early 1970s by the scarcity of information about sexual matters and the use of unreliable birth control methods. Couples ended up with a larger family than what they had considered ideal. With the spread of reliable contraceptive methods and the increase in knowledge about sexual matters starting in the 1970s, the final number of children in a family started to correspond to the ideal at the end of the decade. At the end of the 1980s the final number of children was already smaller than the ideal. Because there are deficiencies in the comparability of the studies made at different points of time, the results presented in the article should be examined with reservations, and seen mainly as demonstrating trends at the group level.

Keywords: family planning, ideal number of children, contraceptive methods, Finland 


\section{Introduction}

The onset of conscious family planning in Finland on the national level is seen to have taken place in 1910, when the decline in fertility exceeded the 10 percent level. According to Notkola $(1994,71)$ this - the beginning of the so-called first population transition - meant not only a definite and permanent decrease in how many children there were in a family, but also a change in the fertility behavior of couples. In contrast to the time of natural fertility, parents no longer continued having children as long as it was biologically possible, instead they attempted to prevent pregnancy after reaching their desired family size.

No significant changes occurred in the methods of birth control available to couples when the first transition began. Withdrawal and abstinence, but also abortions were the main methods couples used when trying to prevent pregnancies and the birth of children. The definite decrease occurring in the number of children had more to do with the skills and wishes of the couple than with techniques (Sievers et al. 1974, 397). In regard to population policy Finns seem to have been rather successful in birth control during the first transition. The average number of children per woman decreased by more than two children from the 1910 s to the mid-1960s .

In examining birth control in regard to social medicine and health policy, knowledge about contraception, the availability of methods of contraception and their use are significant (Sievers et al. 1974, 397). Therefore the beginning of the century was not a very successful period for birth control in this regard. Couples had few opportunities to choose a method best suited to their circumstances and with few adverse effects on the woman's health. Such a stage was not reached until the mid-1960s, when the period van de Kaan (1987) calls the second demographic transition began. This stage is the focus of this article.

The development of family planning from the 1960 s to the 1990 s is examined in this article by first looking at the aims couples have concerning the number of children they want to have and how they want them spaced. We will then examine the conditions necessary for a couple to reach their goals, in other words we will clarify their knowledge about birth control and the availability of methods of contraception. Finally we will assess how successful the couples have been in reaching their goals concerning family size, in other words did their final number of children correspond to the number of children that was their aim and were the children that were born desired and were they spaced correctly. The examination is based mainly on some representative studies of Finland as a whole made in the 1970s to the 1990s. 


\section{Aims related to the number of children and their spacing}

For more than fifty years the ideal number of children has been used to predict the final number of children in a family. In the early years the ideals were accepted indiscriminately. When people answered the questions about ideals with a number, it was understood that couples knew their aims concerning how many children they wanted and were planning the size of their family. It was not until gradually that attention was focused on the discrepancies in the ideals concerning the number of children. The reliability of answers given to questions on ideals proved to be affected, for example, by the concepts concerning the ideal number of children and the wording of questions measuring ideals, the respondent's own life phase and whether ideals were used to study fertility on a group level or differences in fertility between individuals and subgroups (Ritamies et al. 1984, 22).

The questions concerning the ideal number of children in studies carried out at different times have been quite similar, but researchers have still had different views concerning the concepts. In each country researchers have strongly criticized the number of children considered ideal for a family. It has been considered mainly an indication of the pronatalist family size norm prevailing in society (Trent 1980, 309). Personal ideals have usually been measured at the beginning of the marriage and at the time of the interview. Concepts have varied the most regarding ideals at the time of the interview. The concepts ideal, desired, wanted, expected and intended have been used rather freely and inconsistently, making it problematic to compare the results of different studies (see Ritamies et al. 1984, 22-26).

In this article the aims of Finnish couples concerning the number of children they want are examined mainly on the basis of their own ideal number of children - a suitable, preferred and most preferred number of children - at the time of the interview. The suitable number of children is more realistic than the others, based as it is on the couple's own economic and social circumstances, with the preferred and most preferred ideal number of children being somewhat more hypothetical, also demonstrating a liking for children in general. The expected number of children is assumed to be the best predictor of the final number of children. Even though ideals concerning the number of children are not fully comparable, it is assumed that they do demonstrate, at least on a group level, the developmental trend of the last few decades regarding aims concerning the number of children.

It was noted that the ideal number of children among European couples in the 1950s varied between two and three children and was clearly smaller than the American ideal (Stoezel 1955; Glass 1962 and 1968 in Hawthorn 1970, 15). Finnish aims concerning 
the number of children probably did not deviate notably from those observed elsewhere in Europe, because the number of children born per woman in Finland had declined sharply starting in the 1910s. Even though the war meant a temporary rise in fertility, couples were still ready immediately afterwards to accept a small family.

The ideals Finns had concerning the number of children they wanted for themselves in the 1960s were clearly smaller than the general Finnish family ideal and demonstrate that couples were already then aiming for a relatively small number of children. Aims concerning family size did not, in fact, seem to decrease after this. The average ideal size for one's own family remained around 2.5 children for the entire period examined. The ideal noted in 1971 was smaller apparently because it represented a family size suitable for the couple's own economic and social circumstances, and not a preferred or most preferred number of children as in the studies made in other studies. The final number of children was best predicted by the expected number of children, which had remained at an average of 2.4 children since the early 1970 s (Table 1 ).

Table 1. The ideal number of children among Finns from the 1960 s to the 1990 s, averages

$\begin{array}{ccc}\text { Own family's } & \begin{array}{c}\text { Expected number } \\ \text { ideal }\end{array} & \begin{array}{c}\text { Finnish family's } \\ \text { of children }\end{array}\end{array}$

$\begin{array}{llll}1966{ }^{1} \text { Female } & 2.5^{\star} & & \\ 1967^{2} & & 2.9^{*} \\ 1971^{3} \text { Female } & 2.3^{*} & 2.6 & 2.9^{*} \\ 1977^{4} \text { Female } & 2.5^{*} & & 2.9^{*} \\ 1989^{5} \text { Female } & 2.6 & & 2.6 \\ 1992^{6} \text { Male } & 2.5 & 2.4 & 2.5 \\ 1997^{7} \text { Female } & & 2.4 & 2.6 \\ \text { Male } & & & 2.5\end{array}$

Sources: Visuri 1966 unpublished data; Jaakkola 1967 Master's thesis;

Ritamies and Visuri 1975; Ritamies et al. 1984; Nikander 1992 and 1995; Reuna 1997

1) Under-30-year-olds, who visited The Family Federation of Finland's Central

Clinic in 1960-61, the ideal of a family similar to one's own

2) The ideal Finnish family among people from Ristiina

3) 18-54-year-olds married for the first time, the ideal for their own family = a suitable number of children

4)19-45-year-olds, women married for the first time, the ideal for their own family = a preferred number of children

5) 22-51-year-old women, their own ideal = a most preferred number of children

6) 25-49-year-old men, their own ideal = a most preferred number of children

7) 17-60-year-olds, one's own final number of children 
Not only have the ideals concerning family size stabilized from the 1960 s to the 1990 s at a certain level, but they have also become clearly more uniform. Population group differences still existed concerning the ideal number of children in the 1960 s and the early 1970s. For example, young people aimed for a smaller family than those in the older age groups. In the 1980s and 1990s age-specific differences were already quite small. The ideal number of children in a Finnish family and the number of children most preferred in one's own family were surprisingly similar among mothers born at different times, for example (Nikander 1992, 28).

Couples not only plan for a certain number of children, they also plan how they want to space the births. They discuss whether they want to start their family quickly or more slowly, whether it would be good for a second child to be born soon after the first or not until somewhat later etc. What makes examining aims concerning the spacing of children difficult is that so little research data is available. Data about suitable spacing of births is available only in studies made in 1971 and 1977 (Ritamies and Visuri 1975; Riihinen et al. 1980). Even this data is difficult to compare because in the first study the questions concerned ideal birth spacing in general and in the latter the suitable spacing of one's own children.

In the early 1970s Finns considered it ideal to start having children slowly. More than four out of ten women said that it would be suitable for their first child to be born two years after getting married, and almost three out of ten preferred to wait three years (Table 2). Six women out of ten wanted to give birth to their second child two years after the first one, and two out of ten three years after the first (Ritamies and Visuri 1975, 60-64).

Table 2. Suitable spacing for one's first child in 1971 and 1977

1971

As soon as possible

One year

Two years

At least three years

Cannot say

Some other answer

Was pregnant

Total

Average
12.6

43.9

28.2

15.4

100

2.3

2.1
1977

34.1

17.4

19.7

12.0

11.1

5.7

100

Sources: Ritamies and Visuri 1975; Riihinen et al. 1977 
At the end of the decade, however, women felt that it would be more suitable to have their children at a much more rapid pace. One-third wanted their first child to be born as soon as possible and slightly under one-fifth within one year after getting married. The spacing considered suitable for oneself was clearly influenced by actual childbirth. One-third had had their first child within 7 months of getting married and over one-half before their first wedding anniversary (Riihinen et al. 1980, 55-57). The traditional Finnish fertility behavior noted by Nieminen (1963), where 30-40 percent of women were pregnant when they got married, was still apparently ongoing behavior.

Later studies no longer asked about the suitable spacing of childbirth. However, it appears that in the 1980s and the 1990s Finns have moved closer to the spacing of children considered ideal in the 1970 s. Children were born at a slightly slower pace than earlier. The birth of the first child at the end of the 1980s was already an average of 1.6 years after marriage and the second child was born 3.6 years after the first child was born. The spread of consensual unions makes assessment more difficult. In 1989 already over one-fifth of first-born children were born in a consensual union, and among second-born children this was true of about one in ten (Nikander 1992:1, 72, 74, 78).

\section{The conditions necessary for family planning}

The conditions necessary for Finns to realize their aims concerning ideal family size and the spacing of births from the 1960s to the 1990s are the focus of the following examination. We will mainly concentrate on clarifying how knowledge about sex and contraceptive methods developed and how this changed the way people used contraceptive methods.

\section{Knowledge about sex and contraceptive methods}

There were still much lacking in what Finns knew about sex and contraceptive methods in the early 1960s. Talk about sex at home was hushed up, sex education in school was inadequate and the frame of mind behind the educational literature was at about the same level as at the beginning of the century. In the mid-1960s a period of so-called systematic sex education was begun, however (Sysiharju 1969, see Sievers et al. 1974, 158-159), when family education in schools started to include instruction about basic human relationships, dating and sexual rules and provided information about contraceptive methods and their use.

Knowledge about sex is examined by seeing how significant the home, school and other sources were as sources of information at different times and how sufficient the information from these sources was considered. At the same time we will examine how familiar people were with various methods of contraception. 
People's knowledge about sexual matters definitely increased during the period examined. Kontula $(1993,89-90)$ compared the results of studies made in 1971 and 1992 with each other and noted that information provided by the home and by school had increased, with school-provided information increasing more. In the early 1970s 39 percent of the men and 41 percent of the women said that they had received information about sex in their childhood home. Two decades later the corresponding figures were 61 and 64 percent. In this time the percentage having received sex education at school had increased among men from 28 percent to 64 percent and among women from 33 percent to 74 percent.

The sexual information provided by both the home and the school was still considered insufficient in the early 1990s (Table 3). Among the young, the 18-24-year-olds, almost one-half felt that the information they had received at home was insufficient and four out of ten that that received at school was insufficient. Nevertheless, compared to the early 1970 s, the trend had been positive. On the other hand, in the early 1990 s, only 7 percent of those in the older age groups felt the information they had received at school was sufficient, as did 17 percent about that received at home. Because young people were satisfied with the amount of information they had received more often than the others, Kontula (1993, 90-91) sees that discussions about sex and sex education had increased among those who were still young in the 1980 s.

Table 3. Received sufficient sex education in one's childhood home and at school, by age group in 1971 and 1992

Age

$$
\text { Received sufficient sex education, } \%
$$

At home

At school

18-24

1971

25-34

$35-44$

45-54
21

12

7

8
1992

52

34

19

17
1971

17

5

3

2
1992

58

37

18

7

Source: Kontula 1993, 90

Young people have received their information about sex from their friends, in addition to their parents and school. Kontula and Meriläinen $(1988,37)$, for example, noted that discussions about sex were clearly more frequent with friends than with parents. Maunula $(1992,9)$, however, noted that when it was a question of information about birth control methods, 13-17-year-olds said that, above all, they had obtained information from experts such as doctors and nurses, from magazines, television and teachers. In addition, 88 percent of these young people said that they considered the information they had received about methods of contraception sufficient. 
Finns were found to be well familiar with methods of contraception already in the 1970 s (Table 4). When women were asked in studies made in 1971 and 1977 to list all the birth control methods they knew (Sievers et al.; 1974, Riihinen et al. 1980), only 3 percent of the women were not able to mention a single method at the beginning of the decade. The condom and the pill were familiar to nine out of ten women and the IUD and even contraceptive foam were known by a majority of the women. On the other hand, only comparatively few mentioned douche, vaginal suppositories or the rhythm method.

Table 4. Women's knowledge of methods of contraception in 1971 and 1977, \%

1971

Contraceptive pill

IUD

Condom

Withdrawal

Rhythm method

Abstinence

Other methods used by women:

Contraceptive foam

Pessary

Vaginal suppositories/tablets

Douche
91

72

90

50

32

65

49

24

14
1977

95

93

94

30

21

5

Source: Riihinen et al. 1980, 105.

During the next six years a change occurred in the knowledge of women about birth control methods, in that new reliable contraceptive methods became increasingly familiar. Knowledge about the IUD, in particular, increased markedly, which was due to the IUD's not coming into use until the early 1970 s, while the pill had become more popular already in the mid-1960s. On the other hand, fewer women than before knew the more unreliable methods of withdrawal and the rhythm method. Almost all were able to mention at least one method. Knowledge about methods of contraception increased even more clearly when the interviewees were told the methods they had not mentioned and were then asked if they had ever heard of them. At this point everyone was familiar with the condom, the pill and the IUD (Riihinen et al. 1980, 105).

At the end of the 1970s there were still differences between population groups in regard to familiarity with contraceptive methods. These arose especially in regard to the more unreliable methods. The IUD, the pill and the condom, for example, were familiar in all groups, but the more educated the woman was, the more aware she was of the more unreliable methods (Riihinen et al. 1980, 110-111). Apparently when the adverse effects of the pill began to be revealed, some of the highly educated women started 
thinking about switching over to one of the methods less dangerous to their health. Even unreliable methods could be used to prevent pregnancies, when the user had the ability to plan as well as knowledge and skill in using contraception.

Because Finns proved to be highly familiar with contraceptive methods already at the end of the $1970 \mathrm{~s}$, it has apparently not been considered necessary to investigate this in later studies of the adult population. It is probable that familiarity with unreliable methods would have become more rare. When 13-17-year-olds were asked in 1986 about the contraceptive methods they knew, almost all were aware of the condom and the pill. The IUD was mentioned by two-thirds of the adolescents and less than half mentioned foam. On the other hand, hardly anyone considered withdrawal a contraceptive method anymore (Kontula and Meriläinen 1988, 56-57).

The knowledge Finns have about sexual matters thus increased markedly in the four decades under investigation, even though there was still room for improvement in the level of information provided by the home and the school. People were familiar with the very reliable methods of contraception, and it is probably not that important to be aware of other methods. Sterilization was not one of the methods of contraception included in the studies.

\section{Use of contraceptives}

On the basis of the low birthrate, Finns have been regulating family size for a long time, but what methods have they used in different periods to do this? This is a difficult question to answer because there is no data available which would represent the entire country in the period preceding the 1970s. By examining the methods of contraception women of various ages interviewed in 1971 had used during their lifetime, we will get a picture of the methods used in earlier decades to limit the number of births (Table 5, page 38).

The main methods used before the 1970s to decrease the number of children in Finnish families were withdrawal and the condom. The age-specific examination in Table 5 shows that among the women and men aged 45-54, who were interviewed in 1971 and who had been in prime childbearing age in the 1940s and 1950s, about one-half had at some time in their lives used both withdrawal and the condom as methods of contraception. On the other hand, only one in ten mentioned the pill. The condom was more common than withdrawal among the 30-44-year-olds, who had their children in the 1950s and 1960s. The contraceptive pill was also a real alternative for them. Among the youngest, the 18-29-year-olds, only some were starting to have children in 1971. The condom was clearly their favorite method. Withdrawal continued to be common, but the pill had become equally as popular. The growth in the proportion using contraception when moving from the oldest to the youngest age group is clearly visible in the table. 
Table 5. Use of contraceptive methods among people of various ages during their lifetime in $1971, \%^{*}$

$\begin{array}{lcrrr}\text { Nothing } & \mathbf{1 8 - 2 9} & \mathbf{3 0 - 4 4} & \mathbf{4 5 - 5 4} & \text { Total } \\ \text { Douche } & 6 & 11 & \mathbf{2 9} & 13 \\ \text { Rhythm method } & 4 & 3 & 4 & 4 \\ \text { Withdrawal } & 19 & 26 & 21 & 22 \\ \text { Contraceptive foam } & 56 & 58 & 57 & 56 \\ \text { Pessary } & 14 & 21 & 8 & 15 \\ \text { Condom } & 1 & 6 & 6 & 4 \\ \text { Contraceptive pill } & 85 & 71 & 45 & 71 \\ \text { IUD } & 51 & 40 & 10 & 38 \\ \text { N } & 5 & 7 & 1 & 5 \\ & 1164 & 1038 & 634 & 2836\end{array}$

*Percentages refer to all respondents aged 18-54 who have ever had sexual intercourse

Lähde: Leppo, Kimmo 1978, 49

Abortion was not considered a method of contraception in these studies, so it is not possible to use them to assess its significance as a method of birth control in previous decades. According to the data from 19719 percent of the women said they had had an abortion, but the actual number of abortions was evidently at least twice as high (Sievers et al. 1974, 446). Figure 1 shows the development of legal abortions from the early 1950s and also an estimate of illegal abortions before the Abortion Act of 1970. Abortions were still a commonly used method of preventing an undesired birth in the $1950 \mathrm{~s}$ and 1960s. After the Act of 1970 abortions became legal and starting in 1973 they

Figure 1. Legal abortions in 1951-1998 and an estimate of illegal abortions in 1952-1966

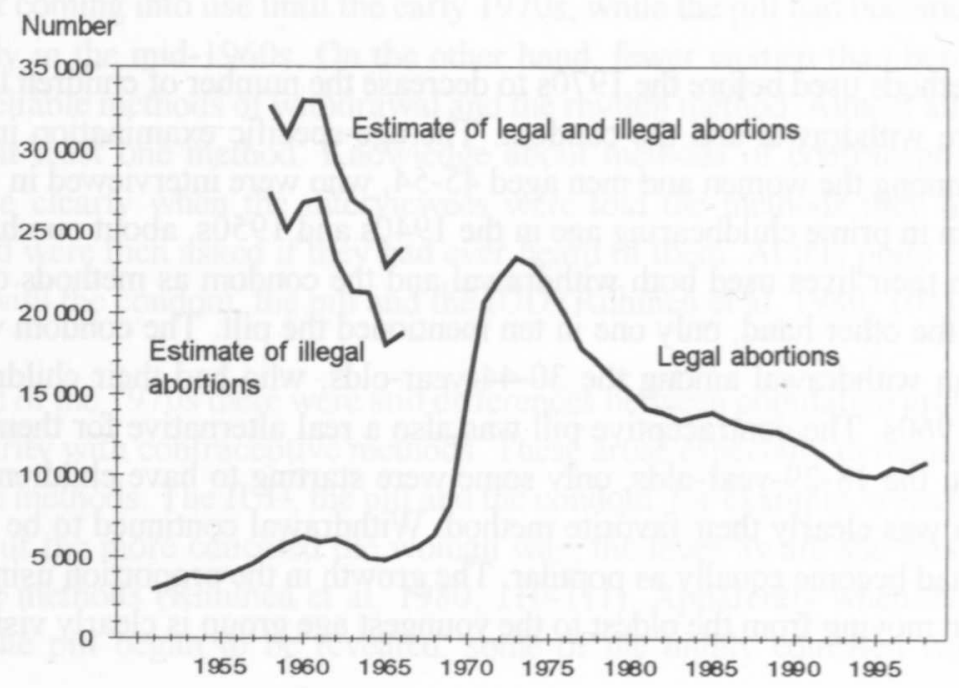


began to decrease continuously. At the end of the 1990s there has again been a slight increase in the number of abortions.

When the methods of contraception used by women during their lifetime are compared for 1971 and 1977 in Table 6, we see that a definite change had occurred. In the beginning of the 1970 s the three most commonly used methods of contraception among women were the condom, withdrawal and the contraceptive pill. At the end of the decade, withdrawal was no longer one of the most popular methods, but the IUD had become as popular as the pill, even though the IUD had hardly even been mentioned six years earlier. The rhythm method, which almost one woman in five mentioned using at the beginning of the decade, had disappeared almost completely. The percentage of women never having used contraception had decreased from 15 percent to 9 percent.

Table 6.Women's use of contraceptive methods during their lifetime in 1971 and 1977

$\begin{array}{lcc} & 1971^{1} & 1977^{2} \\ \text { Contraceptive pill } & 34 & 31 \\ \text { IUD } & 3 & 31 \\ \text { Condom } & 66 & 49 \\ \text { Pessary } & 4 & 34 \\ \text { Contraceptive foam } & 14 & \\ \text { Withdrawal } & 56 & 4 \\ \text { Rhythm method } & 18 & 2 \\ \text { Douche } & 3 & 9 \\ \text { Nothing } & 15 & \end{array}$

1) contraception of 18-54-year-old women during lifetime

2) contraception of 18-54-year-old women during marriage

Source: Sievers et al. 1974, 409 and Rihinen et al. 1980, 115.

The general picture of the development in the use of contraceptive methods will be examined in more detail by looking at how married women in need of contraception in 1971 and 1992 used contraceptive methods (Table 7). Women needing contraception are at risk of getting pregnant. They do not include women who have not had sexual intercourse within the last month, who cannot have a child, who are pregnant and who want to have a child.

The greatest change in the use of contraception among married women in the last two decades has been the marked increase in the use of the IUD and the decrease in the use of unreliable methods. The use of the condom and the pill also decreased, although the condom still remained one of the most commonly used methods in addition to the IUD. In the 1971 study sterilization was not included in the methods of contraception being used. In the beginning of the $1990 \mathrm{~s}$, however, it was just as common as the pill as a method of contraception among married women. A negative factor in the development over two decades was that the proportion using no contraception at all increased somewhat. 
Table 7. The contraceptives used by married women aware of contraceptives in 1971 and $1992, \%$

$\begin{array}{lrr}\text { Condom } & 41 & 28 \\ \text { Contraceptive pill } & 26 & 15 \\ \text { IUD } & 4 & 28 \\ \text { Sterilization } & & 16 \\ \text { Withdrawal } & 20 & \\ \text { Rhythm method } & 1 & 7 \\ \text { Contraceptive foam/ } & 4 & \\ \text { vaginal suppositories } & 4 & 6 \\ \text { Nothing } & 100 & 100 \\ \text { Total } & \\ \text { 1) use of contraception during past month } & \\ \text { 2) use of contraception in last (sexual) intercourse } \\ \text { Sources: Leppo 1978, 64; Erkkola-Kontula 1993, } 352\end{array}$

The situation in the beginning of the 1990s was somewhat different if we look at all women. At that time the pill and the condom were the most commonly used methods with the IUD in third place. Among men the condom was clearly the most common method, with the pill and the IUD clearly being used less (Erkkola - Kontula 1993, 348). Thus contraception among Finns during the period being examined has become more and more centered on three methods: the pill, the condom and the IUD. The condom and the pill are methods used by young people, above all. The pill becomes increasingly less popular after the age of thirty and the IUD more common.

\section{Success in family planning}

With the increase in birth control information and the use of reliable methods of contraception, have couples become more successful from the 1960s to the 1990s in reaching their aims concerning the number of children they wanted and also in having their children when they wanted them? We will attempt to answer this question concerning the realization of the ideal number of children by comparing the aim with the final number of children. On the other hand, the realization of aims concerning the spacing of children can only be examined on the basis of the study made in the beginning of the 1970s.

Stoetzel (1955) noted in the 1950s that the number of children Europeans considered ideal exceeded the number of children they actually had. The ideals varied between 2 and 3 children, but the actual final number of children predicted for the end of the fertile period remained at about two children. Glass $(1962,1968)$, however, noted that the ideals of married couples had remained the same, but that actual fertility was approaching the ideal (see Hawthorn 1971, 15).

When the average ideal number of children among Finnish women is compared using period and cohort total fertility rates in Figure 2, we can see that already in the early 
1970s, at least, the actual number of children women had was smaller than their ideal number of children. There is no information from previous decades about the ideal number of children among women. A comparison with the cohort total fertility rate gives a more reliable picture of the correspondence between the ideal and the actual number of children, for the period rates overestimate the cohort rates up till the early 1970 s and after that they underestimate them (Notkola 1994, 66, 89).

Figure 2. Period and cohort (completed) total fertility rate in Finland in 1900-1997

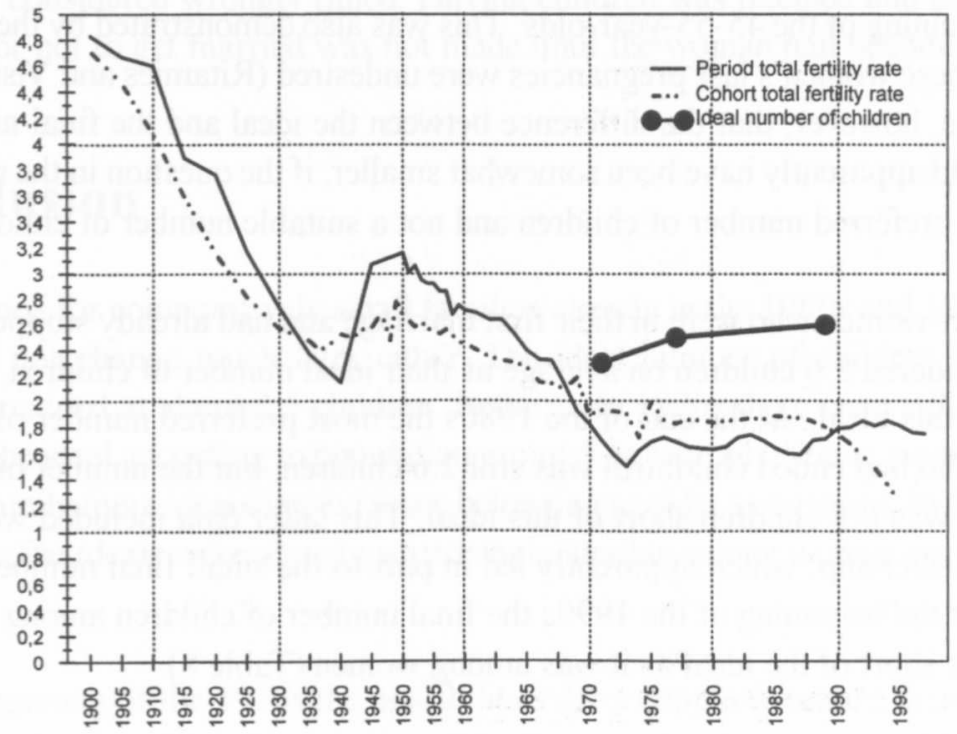

Source: Fougstedt 1977; Myrskylă 1976; Statistics Finland, unpublished statistics: Statistics Finland, Vital statistics 1972-1997

Cohort total fertility rates are placed on the year when the cohort was29/30 years of age.

However, the cohort total fertility rate gives too low a figure of the final number of children the couple will have, because the number of children is given as a ratio to all women. On the other hand, the ideal number of children in the 1970s was the ideal of married women, with only the ideal at the end of the 1980s representing the ideal of all women. Lindgren $(1975,52)$ noted that in the early decades of the 1900 s about 18 percent of the women never gave birth, because they were never married or could not have or did not want to have a child and even later this portion has remained around 15 percent. Thus we could assume that the actual final average number of children of a couple would be at least 0.5 children higher than the cohort total fertility rate in the 1970s. The final number of children would thus be quite close to the ideal number of children in the 1970 s, but when approaching the end of the 1980s the number of children would already stop under the ideal. 
If we examine the realization of aims concerning the number of children of those who have already completed their families by comparing the ideal with either the expected number of children or the actual number of children, the result deviates from what was presented above (Table 8). In 1971 married women who were no longer bearing children considered a suitable number of children at the time of the interview to be, in view of their economic and social situation, an average of 2.5 children, while among men the ideal was 2.2 (minimum). The women had ended up, however, with 0.6 and the men with 0.9 more children than their ideal, which shows that there were still some faults in the family planning of the $45-55$-year-olds. This was also demonstrated by the fact that one-fifth of these women's last pregnancies were undesired (Ritamies and Visuri 1975, 77). It is true, however, that the difference between the ideal and the final number of children would apparently have been somewhat smaller, if the question in the study had been about a preferred number of children and not a suitable number of children.

Six years later women who were in their first marriage and had already stopped having children considered 2.6 children on average as their ideal number of children, and they also realized this ideal. At the end of the 1980s the most preferred number of children for women who had ended childbirth was still 2.6 children, but the number of children they had had was 0.5 children short of this ideal. This latter data included women not living in a partnership, which apparently led in part to the small final number of children. Also at the beginning of the 1990s the final number of children among men was the equally as short of the ideal as it was among women (Table 8).

Table 8 . The ideal number of children among people who have ended childbearing according to gender in various studies.

\section{Suitable/preferred Expected/final Difference number of children number of children}

$\begin{array}{lllll}1971^{1} & \text { Women } & 2.5 & 3.1 & 0.6 \\ & \text { Men } & 2.2 & 3.1 & 0.9 \\ 1977^{2} & \text { Women } & 2.6 & 2.6 & 0 \\ 1989^{3} & \text { Women } & 2.6 & 2.1 & -0.5 \\ 1992^{4} & \text { Men } & 2.4 & 1.8 & -0.6\end{array}$

Sources: Ritamies and Visuri 1975, 26,30; Ritamies et al. 1984, 128-129 Nikander, 1992, 28; Nikander 1995, 48

1) 45-54-year-old married women and men

2) 40-45-year-old married women (Ritamies et al. 1984, 128-129)

3) 47-51-year-old women

4) 45-49-year-old men 
It is not possible on the basis of these studies to clarify the extent to which couples have succeeded in realizing the ideal they had regarding how they wanted their children to be spaced. According to the women interviewed in 1971 a marked portion of their pregnancies had begun earlier than planned. Among first pregnancies 43 percent were timed wrong, as were one-third of second and third pregnancies (Ritamies and Visuri 1975, 77). It is probable, however, that the proportion of wrongly timed pregnancies gradually decreased. The first pregnancy took place later and later. Even though the child was often born quite soon after the marriage had begun or even before, the pregnancy was not often considered wrongly timed. Having children was planned and the decision of whether or not to get married was not made until the woman had become pregnant.

\section{Conclusion}

Finns aimed for comparatively small families already in the 1960s and 1970s, and this ideal did not change much later either. The ideal number of children in one's own family remained at about 2.5 children. In the early 1970 s there were still some differences in the ideal according to population group. For example, young people considered a small family more ideal than did those belonging to older age groups. In the 1980s and the 1990s the ideals were already surprisingly similar among women born at different times.

In the beginning of the 1970 s the possibilities for a couple to realize their ideal family size were decreased by the scarcity of birth control information and by the use of unreliable methods of contraception. Even in the early 1990s information obtained in the home and at school about sexual matters was considered insufficient. People were well aware of reliable methods of contraception already in the 1970s. The methods of birth control people were actually still using in the early 1970s, though, were often unreliable methods such as withdrawal. On the other hand, in the early 1990s contraception mainly meant the use of three methods: the condom, the IUD and the pill.

The ideals couples had concerning family size were not yet realized in the early 1970s. The final number of children exceeded the ideal and demonstrated that family planning was still unsuccessful. At the end of the decade the actual number of children already corresponded to the ideal number and at the end of the 1980s actually stopped short of the ideal. Even though on the group level Finnish couples appeared to have been able to plan the number of children they were having already at the end of the 1970 s, on the individual level there were naturally also some failures, pregnancies which began too soon or pregnancies that were undesired altogether. Some of the undesired pregnancies were apparently also aborted. 
The results presented here should be regarded with some reservations, and seen mainly as trends at the group level. Examining the success of family planning on the basis of studies made at different points in time is not without its problems. The studies covered here representing the entire country have not been planned in a way that would make a reliable comparison of key family planning factors possible.

For one, the concepts of ideal and the wording of questions measuring these concepts vary in the studies made at different times, making comparison more difficult. A suitable number of children was more realistic than a preferred or most preferred number of children and thus apparently somewhat smaller. The final number of children, again, was determined on the basis of the expected number of children or the actual final number of children among those who had completed their fertile period. Among the younger age groups, on the other hand, the expected number of children was the ideal, which can still change.

A second problematic factor was using total fertility rates as indicators of the final number of children, because these rates also included women who were not living in a partnership. Total fertility thus apparently remained below the actual final number of children and explains Stoetzel's (1955) observation that the final number of children among Europeans was less than their ideal number of children already in the 1950 s.

How reliable the ideal number of children is as an aim that people actually try to realize also depends much on the phase of life the people being studied are in. In crosssectional data it has been found that the older age groups shape their ideal number of children so that it will correspond to their actual number of children, because it is not easy to admit to being unsuccessful in family planning. On the other hand, negative experiences with a large family can also cause a decrease in the ideal from what it was originally. Correspondingly, the ideals of young people are often unrealistic and they may change later along with experience (Ritamies et al. 1984, 29-30).

Finns can be considered to have been rather successful in family planning for a long time, because the fertility rates have decreased. However, not until in the four decades examined in this article, in the 1960s to the 1990s, can couples be considered as having succeeded in planning the size of their family in regard to the well-being of the couple's relationship and the woman's health. Even though it was possible to decrease the birthrate earlier using withdrawal, abstinence and abortion, this could not have benefited the couple's sexual well-being nor the woman's health. Not until increased knowledge about contraception and the coming onto the market of new reliable methods of contraception has it been possible for each couple to be able to choose from among various methods the method of contraception best supporting the well-being of their own relationship and the woman's health. 


\section{Sources:}

Erkkola, Risto and Osmo Kontula. 1993. Syntyvyyden säännöstely (Birth control). In Suomalainen seksi (Finnish Sex), edited by Osmo Kontula and Elina Haavio-Mannila. Porvoo-Helsinki-Juva: WSOY.

Hawthorn, Geoffrey. 1970. The Sociology of Fertility. London: Collier-Macmillan.

Kontula, Osmo. 1993. Sukupuolielämän aloittaminen (Starting sexual relations). In Suomalainen seksi (Finnish Sex), edited by Osmo Kontula and Elina Haavio-Mannila. PorvooHelsinki-Juva: WSOY.

Kontula, Osmo and Jouni Meriläinen. 1988. Nuorten kypsyminen seurusteluun ja seksualisuuteen (How Young People Mature for Dating and Sexuality). Lääkintöhallituksen julkaisuja. Terveyskasvatus Sarja Tutkimukset 9/1988. Helsinki: Lääkintöhallitus.

Leppo, Kimmo. 1978. Contraception in Finland in a Public Health Perspective. Väestöntutkimuslaitoksen julkaisusarja D Nro 5. Helsinki: Väestöntutkimuslaitos.

Lindgren, Jarl. 1975. Suomalaisen syntyvyyden kehityskuva (The Development of Finnish Fertility). Väestöntutkimuslaitoksen julkaisuja B:31. Helsinki: Väestöntutkimuslaitos.

Maunula, Minna. 1992. Nuoret ja kondomi. Selvitys nuorten ehkäisyyn liittyvistä tiedoista, taidoista ja toiveista (Young People and the Condom. A Study of Information, Skills and Hopes Related to Contraception among the Young). Helsinki: Väestöliitto, Väestöntutukimuslaitos.

Nieminen, Armas. 1963. Premarital Pregnancy in Finland. Moniste.

Nikander, Timo. Naisen elämänkulku ja perheellistyminen (The Life Course of Women and Family Formation). SVT Väestö 1992:1. Helsinki: Tilastokeskus.

Nikander, Timo. Suomalaisnaisen perheellistyminen (The Family Formation of Finnish Women). SVT Väestö 1992:10. Helsinki: Tilastokeskus.

Nikander, Timo. Suomalaismiehen perheellistyminen (The Family Formation of Finnish Men). SVT Väestö 1995:1. Helsinki: Tilastokeskus.

Notkola, Irma-Leena. 1994. Hedelmällisyys (Fertility). In Suomen Väestö (The Population of Finland), edited by Seppo Koskinen, Tuija Martelin, Irma-Leena Notkola, Veijo Notkola and Kari Pitkänen. Helsinki: Gaudeamus.

Notkola, Irma-Leena. 1989. Luonnollisesta hedelmällisyydestä lapsirajoituikseen. Mikrodemografinen tutkimus hedelmällisyyden transitioista (From Natural Fertility to Limiting Children. A Microdemographic Study of the Fertility Transition). Suomen Väestötieteen Yhdistyksen julkaisuja N:o 12. Helsinki: Suomen Väestötieteen Yhdistys.

Riihinen, Olavi, Aimo Pulkkinen and Marketta Ritamies. 1980. Suomalaisen perheen lapsiluku (The Number of Children in Finnish Families). Väestöntutkimuslaitoksen julkaisusarja D, N:o 7. Helsinki: Väestöntutkimuslaitos.

Ritamies, Marketta and Elina Visuri. 1975. Suomalaisten perhekoko - sattuma vai suunnitelma (Finnish Family Size - A Mistake or Planned). Väestöntutkimuslaitoksen julkaisusarja D, N:o 1. Helsinki: Väestöntutkimuslaitos.

Ritamies, Marketta, Olavi Riihinen, Heli Penttinen and Aimo Pulkkinen. 1984. Lapsilukuihanne - toive vai tavoite (The Ideal Number of Children - A Hope or an Aim). Väestöntutkímuslaitoksen julkaisusarja D, Nro 13. Helsinki: Väestöntutkimuslaitos, Väestöliitto.

Sievers, Kai, Osmo Koskelainen and Kimmo Leppo. 1974. Suomalaisten sukupuolielämä (The Sex Life of Finns). Porvoo-Helsinki: WSOY. 